\title{
Perception of nursing professionals on patient safety culture
}

\author{
Percepção dos profissionais de enfermagem sobre a cultura de segurança do paciente \\ La perspectiva de los profesionales de enfermería acerca de la cultura de seguridad del paciente
}

Juliana Cristina Abbate Tondo', Edinêis de Brito Guirardello'
'Universidade Estadual de Campinas, School of Nursing, Postgraduate Program in Nursing. Campinas, São Paulo, Brazil.
How to cite this article:
Tondo JCA, Guirardello EB. Perception of nursing professionals on patient safety culture.
Rev Bras Enferm [Internet]. 2017;70(6):1284-90. DOI: http://dx.doi.org/10.1590/0034-7167-2016-0010

Submission: 01-20-2016 Approval: 04-04-2017

RESUMO

Objetivo: Avaliar a percepção dos profissionais de enfermagem sobre o clima de segurança, verificar se a mesma difere entre as categorias e se existe correlação entre os domínios do SAQ e variáveis pessoais e profissionais. Método: Estudo quantitativo e transversal realizado em um hospital de ensino no interior do Estado de São Paulo. A coleta de dados ocorreu no período de abril a julho de 2014, com a aplicação do Questionário de Atitudes de Segurança. Resultados: Participaram do estudo 259 profissionais. O domínio satisfação no trabalho obteve escores acima de 75 para ambas as categorias. A percepção do clima de segurança diferiu entre as categorias para a maioria dos domínios, exceto para o reconhecimento do estresse, e existe correlação entre cinco domínios do SAQ e as variáveis tempo de experiência e intenção de deixar a profissão. Conclusão: Conhecer a percepção dos profissionais sobre o clima de segurança contribuirá para uma assistência segura.

Descritores: Segurança do Paciente; Qualidade da Assistência à Saúde; Ambiente de Instituições de Saúde; Recursos Humanos de Enfermagem; Enfermagem.

\begin{abstract}
Objective: To evaluate nursing professionals' perception on safety climate, to check if this perception differs between categories and if there is correlation between the Safety Attitude Questionaire (SAQ) domains and personal and professional variables. Method: Quantitative and transversal study held in a teaching hospital in the countryside of São Paulo, in Brazil. Data collection occurred in the period from April to July 2014, with the application of the SAQ. Results: 259 professionals participated in the study. The domain job satisfaction obtained scores above 75 for both categories. The perception of safety climate differed between the categories for most areas, except for the recognition of stress, and there is correlation between five SAQ domains and the variables time of experience and intention to leave the profession. Conclusion: Knowing the professionals' perception on safety climate will contribute to a secure assistance.
\end{abstract}

Descriptors: Patient Safety; Quality of Health Care; Environment of Health Institutions; Nursing Human Resources; Nursing.

\section{RESUMEN}

Objetivo: Analizar la perspectiva de los profesionales de enfermería acerca de la cultura de seguridad del paciente, comprobar si es la misma entre las categorías y si existe correlación entre los dominios del Cuestionario de Actitudes Seguras (SAQ por su sigla en inglés) y las variables personales y profesionales. Método: Estudio cuantitativo y transversal realizado en un hospital escuela en el interior del estado de São Paulo. En la recolección de datos llevada a cabo de abril a julio de 2014 se empleó el Cuestionario de Actitudes Seguras. Resultados: Del estudio participaron 259 profesionales de enfermería. El dominio satisfacción con el trabajo presentó puntaje mayor que 75 en ambas categorías. La perspectiva sobre la cultura de seguridad no fue la misma entre las categorías estudiadas en la mayoría de los dominios, excepto la del reconocimiento del estrés, y hubo correlación entre los cinco dominios del SAQ y las variables tiempo de experiencia e intención de cambiar de profesión. Conclusión: Conocer la perspectiva de estos profesionales sobre la cultura de seguridad puede contribuir a una asistencia segura.

Descriptores: Seguridad del Paciente; Calidad de la Atención de Salud; Ambiente de Instituciones de Salud; Recursos Humanos de Enfermería; Enfermería. 


\section{INTRODUCTION}

Patient safety should be considered as a prerequisite of thematic assistance and is essential in the face of the current scenario of growth of health care demands and the increased level of complexity in the various areas of health services ${ }^{(1-4)}$. The concern for patient safety was reaffirmed with the publication of the report "to err is human" by the Institute of Medicine in the United States of America, which estimated the annual occurrence of 44,000 and 98,000 deaths of patients in hospitals, occasioned by errors associated with health care, which could be prevented ${ }^{(5-6)}$.

Patient safety is defined as reducing the risk of unnecessary damage during assistance processes and the use of the best practices to achieve optimal results for the patient ${ }^{(1)}$.

The perception of nursing professionals in relation to their work environment can influence the way they see themselves professionally and the way they perform their activities, which can reflect directly on patient safety ${ }^{(7)}$. In a daily basis, nursing professionals deal with constant dynamism situations, whether they are related to the clinical conditions of the patients, to human resources management (such as absenteeism and staff turnover) or to technological aspects; often are the times when they are under stress, which may also influence the safety of the health assistance. Thus, it is essential to recognize processes and flaws, by establishing measures to prevent the occurrence of errors and improve communication with those involved in all care processes $^{(8)}$.

In this context, it is necessary to understand the organizational environment in health institutions, especially regarding culture and the safety climate, since the risk for occurrence of errors can result in damage to the patient. For health care services, the safety culture comprises the global set of climate perceptions presented by professionals in relation to the organization's commitment to security issues ${ }^{(9)}$.

Safety culture is a major factor guiding the behavior of health professionals. However, the change of culture is not easy to be held, because it is a slow process, which develops itself into a long period of time ${ }^{(9)}$.

The evaluation of the safety culture in an institution can be obtained through the perception of safety climate reported by its professionals ${ }^{(10)}$. Safety climate is defined as the measure of individual attitudes and perceptions of the characteristics of the safety culture among workers of the organization, which may vary within the institution ${ }^{(10)}$.

The research of safety climate is considered an indicator of safety performance when compared with the rates of errors and damage, considered indicators of result ${ }^{(9)}$. It is important to understand and predict significant organizational results ${ }^{(11)}$, since the climate and culture affect the quality of care and the outcomes for the patient due to its direct influence in the processes of health care $\mathrm{e}^{(10,12)}$.

Safety climate in health institutions represents an essential component to ensure a secure environment. Considering that the nursing staff is the largest category of professionals responsible for assisting patients, the issue of this research consists of knowing the perception of nursing professionals on the safety attitude in the institution.

The assessment of safety climate under the perception of nursing professionals can subsidize nursing managers and administrators in identifying the constraints and weaknesses that exist in the organization, as well as in the implementation of strategies that encourage the construction of a safety culture $^{(6,10)}$

Therefore, this study aimed to evaluate the perception of nursing professionals on safety climate, as well as to check if the this perception differs between professional categories and if there is correlation between the SAQ domains and personal and professional variables.

\section{METHOD}

\section{Ethical aspects}

The study was approved by the Research Ethics Committee. After being informed of the objectives, risks and benefits of the study, as well as confidentiality and anonymity, all participants signed an informed consent form, according to Resolution 466/12.

\section{Study design, local of study and period}

Quantitative and transversal study held in a public and teaching hospital, located in the countryside of São Paulo in Brazil. The institution had level 3 of accreditation by the National Accreditation Organization and international accreditation by Accreditation Canada.

\section{Population and sample, inclusion and exclusion criteria}

The population considered for the calculation of the sample size consisted of 329 professionals, being 65 nurses and 264 technicians and auxiliary staff. It was assumed a sampling error of $3 \%$ and a level of significance of $5 \%$. With that, the sample size was calculated in 252 professionals, consisting of 50 nurses and 202 nursing assistants and technicians.

The sample consisted of nurses, technicians and nursing assistants who met the criteria for inclusion, namely: to exercise assistance activities on the unit and to have a minimum of experience in the institution equal to or greater than three months. The minimum time of three months experience was considered as a criterion for inclusion, because it allows the professional to fit and to be familiar with his workplace. It were excluded from the sample the professionals who, during the period of data collection, were under license for any reasons or vacation.

\section{Study protocol}

For the data collection, it were used the file for personal and professional characterization and the Brazilian version of the Safety Attitude Questionnaire $(\mathrm{SAQ})^{(13)}$. The file contains personal (age, sex and marital status) and professional (professional training time, time of experience in institution, time of experience in unit and intention to leave the profession) data. 
The SAQ is an instrument consisting of 41 items distributed in eight areas: climate of teamwork, safety climate, job satisfaction, stress recognition, perception of unit management and hospital management, working conditions and safe behavior.

The scale of Likert-type response is, with five alternative responses: strongly disagree (zero point), partially disagree (25 points), neutral (50 points), partially agree ( 75 points) and totally agree (100 points). The alternative "does not apply" is not considered in the scores of scales. The negative connotation items (items 2, 11 and 36) are encoded in reverse, and score of each domain is obtained by the sum of the scores, divided by the total number of questions. Scores above 75 indicates the perception of a safe environment for the patient. The instrument offers satisfactory reliability, featuring Cronbach's alpha values that ranged from 0.70 to $0.89^{(13)}$ and, for the present study, ranged from 0.70 to 0.83 .

Prior to data collection, the nursing staff of the institution contacted the technical responsible by for authorization and completion of the study. Data were collected in the period from April to June 2014, with survey respondents approached in their environment and during working time, by combining a date and time for delivery of the instruments to the researcher responsible for the study. Those who attended the inclusion criteria were invited to participate in the study and, after receiving information about the completion of the research instruments, each participant received an envelope containing the informed consent form, the characterization file and the Brazilian version of the SAQ.

\section{Analysis of the results and statistics}

The data collected were entered into a spreadsheet in Microsoft $^{\circledR}$ Excel and analyzed through the Statistical Analysis System (SAS) version 9.4 for Windows ${ }^{\circledR}$. Descriptive analysis was performed of the categorical variables (sex, marital status and intention to leave the profession) and numeric variables (age, time of formation, time of experience in the unit and time of experience in the institution).

Prior to the choice of the statistical tests, the adherence of the normal distribution was evaluated using the KolmogorovSmirnov test. To evaluate differences of perception of the safety climate between the professionals, we used the MannWhitney test, considering the categories nurses and, as a single category, technicians and nursing assistants. The correlation between the variables was evaluated by Spearman correlation, from which it were considered the coefficients of -1 to 1 . Values close to the extremes indicate a high degree of correlation; values close to zero indicate low correlation; and values equal to zero indicates the absence of correlation $^{(14)}$. For all statistical analyses performed, we adopted a significance level of $5 \%$.

\section{RESULTS}

Two hundred and fifty-nine nursing professionals participated in this study, of which 203 (78.4\%) were nursing technicians, $10(3.9 \%)$ nursing assistants and $46(17.8 \%)$ nurses. The majority were female (89.2\%), married (62.6\%) and with an average age of 37.2 years $(\min =19 ; \max =60$, $\operatorname{med}=36$, $\mathrm{SD} \pm 9.1)$. The return rate was $78 \%$ for nurses and $67.2 \%$ for technicians and nursing assistants.

The time for the training of professionals was an average of 7.8 years $(\min .=3$ months; $\max .=32$ years; $\mathrm{SD} \pm 6)$, the average time to work at the institution was 5 years $(\mathrm{min} .=3$ months; $\max .=36 ; \mathrm{SD} \pm 5$ ) and had a time of experience in the unit of 4.1 years $(\min .=1$ month and max. $=24$ years; $\mathrm{SD} \pm 4.3)$.

For descriptive analysis of the SAQ, we considered the distribution of responses for domains (Table 1). It was verified that the domain job satisfaction obtained an average of 81.97 points (range from 0 to 100 points), followed by domains safe behavior, teamwork and safety climate, whose average scores ranged from 70.02 to 73.86 points and the domains stress recognition, perception of unit management and hospital management obtained the smallest averages (Table 1).

In a second moment, we assessed the frequency of responses by SAQ domains between professional categories, resulting in significant statistical differences for most fields, with the exception of stress recognition (Table 2).

In Table 3 there are results of the correlation between the average scores of the SAQ domains and the variables age, time of formation, time of work in the unit, time of work in the institution and intention to leave the profession in the next 12 months. It was noted that there is correlation between most of the domains of the SAQ and the intention to leave the profession and time of experience on the unit and in the institution. The domains stress recognition showed no correlation with any of the variables under study, as well as the age also did not result in correlation with any of the SAQ domains.

Table 1 - Scores by domains of Security Attitudes Questionnaire submitted by nursing professionals of teaching hospital, Campinas, São Paulo, Brazil, 2014

\begin{tabular}{|c|c|c|c|}
\hline SAQ domains & Average & $\begin{array}{l}\text { Standard } \\
\text { Deviation }\end{array}$ & Median \\
\hline Job satisfaction & 81.97 & 18.25 & 85.00 \\
\hline Safe behavior & 73.86 & 23.74 & 75.00 \\
\hline Climate of teamwork & 73.80 & 17.43 & 75.00 \\
\hline Safety climate & 70.02 & 17.81 & 71.43 \\
\hline Working conditions & 65.96 & 24.47 & 66.67 \\
\hline Perception of unit management & 59.91 & 20.00 & 58.33 \\
\hline Stress recognition & 59.64 & 25.44 & 62.50 \\
\hline Perception of hospital management & 59.61 & 19.13 & 58.33 \\
\hline
\end{tabular}

Note: SAQ - Safety Attitudes Questionnaire 
Table 2 - Comparison between nurses, nursing technicians (NT) and nursing assistants (NA) in the domains of Security Attitudes Questionnaire, Campinas, São Paulo, Brazil, 2014

\begin{tabular}{|c|c|c|c|c|c|}
\hline SAQ domains & Category & Average & Standard deviation & Median & $p$ value \\
\hline \multirow{2}{*}{ Climate of teamwork } & Nurse & 80.82 & 11.63 & 79.17 & \multirow{2}{*}{$0.0060^{*}$} \\
\hline & NT/NA & 72.23 & 18.16 & 75.00 & \\
\hline \multirow{2}{*}{ Safety climate } & Nurse & 80.53 & 14.49 & 82.14 & \multirow{2}{*}{$<0.0001^{*}$} \\
\hline & NT/NA & 67.66 & 17.70 & 70.83 & \\
\hline \multirow{2}{*}{ Job satisfaction } & Nurse & 86.41 & 14.97 & 92.50 & \multirow{2}{*}{$0.0535^{*}$} \\
\hline & NT/NA & 81.03 & 18.83 & 85.00 & \\
\hline \multirow{2}{*}{ Stress recognition } & Nurse & 64.39 & 21.15 & 62.50 & \multirow{2}{*}{0.2066} \\
\hline & NT/NA & 58.45 & 26.20 & 56.25 & \\
\hline \multirow{2}{*}{ Perception of unit management } & Nurse & 70.91 & 14.89 & 70.83 & \multirow{2}{*}{$<0.0001 *$} \\
\hline & NT/NA & 57.59 & 20.19 & 58.33 & \\
\hline \multirow{2}{*}{ Perception of hospital management } & Nurse & 68.54 & 17.07 & 70.83 & \multirow{2}{*}{$0.0004 *$} \\
\hline & NT/NA & 57.72 & 19.07 & 58.33 & \\
\hline \multirow{2}{*}{ Working conditions } & Nurse & 73.41 & 18.70 & 75.00 & \multirow{2}{*}{$0.0445^{*}$} \\
\hline & NT/NA & 64.25 & 25.35 & 66.67 & \\
\hline \multirow{2}{*}{ Safe behavior } & Nurse & 83.70 & 15.99 & 83.33 & \multirow{2}{*}{$0.0036^{*}$} \\
\hline & NT/NA & 71.67 & 24.70 & 75.00 & \\
\hline
\end{tabular}

Note: *Mann-Whitney tests $p \leq 0.05 ;$ NT - nursing technicians; NA - nursing assistants; SAQ - Safety Attitudes Questionnaire.

Table 3 - Spearman correlation coefficients between the scores of the domains of the Safety Attitudes Questionnaire and personal and professional variables, Campinas, São Paulo, Brazil, 2014

\begin{tabular}{|c|c|c|c|c|c|}
\hline SAQ domains & Age & Training time & $\begin{array}{l}\text { Time of } \\
\text { experience } \\
\text { in the unit }\end{array}$ & $\begin{array}{c}\text { Time of } \\
\text { experience } \\
\text { in the institution }\end{array}$ & $\begin{array}{l}\text { Intention } \\
\text { of leaving } \\
\text { profession }\end{array}$ \\
\hline Climate of teamwork & -0.0185 & -0.0229 & $-0.2112^{*}$ & $-0.2003 *$ & $-0.1496 *$ \\
\hline Safety climate & 0.0152 & -0.0376 & $-0.1813^{*}$ & $-0.1412 *$ & $-0.1742 *$ \\
\hline Job satisfaction & -0.0278 & $-0.1503 *$ & $-0.2391 *$ & $-0.2165^{*}$ & $-0.2661 * *$ \\
\hline Stress recognition & 0.0928 & 0.0726 & 0.0589 & 0.0867 & 0.0891 \\
\hline Perception of unit management & 0.0107 & -0.0849 & $-0.1285^{*}$ & -0.1181 & $-0.1419 *$ \\
\hline Perception of hospital management & 0.0396 & -0.0681 & $-0.1619 *$ & -0.1112 & -0.0706 \\
\hline Working conditions & 0.0842 & -0.0453 & $-0.2016^{*}$ & $-0.1579 *$ & $-0.2412^{*}$ \\
\hline Safe behavior & 0.0223 & -0.0639 & $-0.2186^{*}$ & $-0.1747^{*}$ & $-0.2171^{*}$ \\
\hline
\end{tabular}

Note: Spearman's rank correlation coefficient: ${ }^{*} p \leq 0.05 ;{ }^{*} p \leq 0.0001 ;$ SAQ - Safety Attitudes Questionnaire.

\section{DISCUSSION}

This is a sample of professionals in its majority composed of young adult female and married. The predominance of females in the profession of nursing is justified by the historical trajectory of the profession and confirms other studies ${ }^{(15-18)}$. We highlight that the working time in the institution and the experience in the unit resembled international studies ${ }^{(17,19-20)}$ and a national study ${ }^{(15)}$, in which they evaluated the safety climate in both clinical and intensive care units, but we noted that the values were lower than those of other studies ${ }^{(16,18)}$.
In the assessment of SAQ domains, the findings showed that only the domains job satisfaction, evidenced by the positive experiences with the work, it was perceived by professionals as positive for the attitude of safety at the workplace. This result is in accordance with international studies, which evaluated the safety climate in intensive care units ${ }^{(17,21)}$ and in hospitals in the United States of America and in Switzerland ${ }^{(19)}$, and a Brazilian study, which evaluated the safety climate in surgical clinic units ${ }^{(15)}$. The perception of a safety positive attitude in the workplace can be evidenced by the job satisfaction and professional autonomy as well as by the 
commitment and the performance of a quality assistance ${ }^{(17,19)}$.

Regarding the other SAQ domains, climate of teamwork, safety climate and safe behavior presented averages between 70 and 74 points. Of these, the domains climate of teamwork and safety climate obtained values close to those found in other studies ${ }^{(17,19,21)}$ and superior to those found in literature studies ${ }^{(13,21)}$

In this study, the domains climate of teamwork and safe behavior obtained score of 73.8 , i.e., value very close to the concept of positive safety climate for patient safety. Such finding is important because studies of the climate and the culture of safety ${ }^{(22)}$ indicate that teamwork, developed through effective communication, can reflect in mutual collaboration among professionals, providing positive results, such as job satisfaction and efficiency in the activities ${ }^{(22)}$.

Domains that stand out with lower scores were perception of hospital management, perception of stress and perception of unit management. The lowest scores for these areas suggest low approval of management actions on the issues of security, corroborating national ${ }^{(15,18)}$ and international ${ }^{(15,19-21)}$ studies.

In relation to the perception of management of the institutions and the management of patient safety climate, study conducted in China, aiming to explore the perceptions of nurses in relation to patient safety culture and to identify the associated factors, presented four significant factors to the positive perception of the climate of security by professionals. Among the factors, two are related to the reliability and management commitment to safety, which should stimulate the commitment of the professionals with security issues, setting and reinforcing standards and safe practices, generating a positive perception of patient safety culture ${ }^{(22)}$.

The low-scoring identified in this study for the domain stress recognition has also been reported by other authors in the literature ${ }^{(13,16,19-21)}$. Still with prominence for this domain, study conducted to evaluate the internal validity of this construct pointed out that this construct do not fit the assessment of global safety climate of the SAQ, justifying that this domain evaluates the perception of the professional regarding skills, unlike other domains, that evaluate the perception of the professional regarding the workplace or the organizational unit as a whole $\mathrm{e}^{(12)}$. These same authors suggest reviewing the relevance of that domain as a variable of the SAQ for evaluating patient safety climate.

In assessing the perception of safety climate between the occupational categories, we observed significant statistical differences for most domains, except for the domain stress recognition. This finding shows that nurses perceive a more positive safety climate when compared with technicians and nursing assistants. It is important to highlight that the nurses perceive a climate of positive safety, demonstrated by values greater than 75 points for the domains climate of teamwork, safety climate, job satisfaction and safe behavior. This result may be related to professional training of nurses, directed not only to assistance, but also to management and teaching areas, which may favor a wide view of the service provided.

It should be noted that such aspect can be considered important for the management of this institution for portraying a safe environment for the patient and for professionals in the perception of nurses, which occupy a prominent role in the care and management of quality in health services.

The study also made possible the understanding of the relationship between SAQ domains and the variables age, training time, time of experience in unit, time of experience in institution and intention to leave the profession. In this sense, there is a negative correlation between job satisfaction and the variables training time, time of experience in unit, time of experience in the institution and intention to leave the profession. Therefore, the longer the training time, the time of experience in unit and in the institution and the intention to leave the profession, the less the job satisfaction. The workplace exerts influence on the behavior of nursing professionals, and may favor the intention to leave the profession ${ }^{(23)}$.

Although all values of Spearman's rank correlation coefficient showed correlation with all independent variables evaluated, the correlation between the variables intention to leave the profession and job satisfaction presented great statistical significance $(\rho=-0.266 ; p \leq 0.0001)$. This finding can be interpreted as evidence of discriminant validity for this SAQ domain, since it has been demonstrated that the higher the intention to leave the profession, the less the job satisfaction.

On the other hand, the study pointed out the absence of correlation between the scores of SAQ domains the age of the professionals. The same is observed with the domain stress recognition, which showed no correlation with any variable in question. These results differ from studies in which the younger nurses, i.e., with less than 30 years, reported greater confidence in dealing with stressor factors in relation to older nurses ${ }^{(17,20)}$.

There is evidence of negative correlation between domains teamwork, safety climate, working conditions and safe behavior and the variables time in the unit, time in the institution and intention to leave the profession, which indicates that the greater the time of work in the unit and the institution, and the intention to leave the profession, the lower the score of these domains. These findings corroborate a study that assessed the impact of adverse conditions in the intention to leave the profession. Professionals who receive the necessary support of their team and of their supervisors report lower intention to leave the profession ${ }^{(24)}$.

The domain perception of unit management presented evidence of negative correlation with the variables time of experience in the unit and intention to leave the profession, meaning that the bigger the time of experience in unit and intention to leave the profession, the lower the score of the domain. As for the domain perception of hospital management, there is evidence of negative correlation only with the variable time in the unit, pointing out that, the longer the time of work in the unit, the worst the professional perception regarding the management of the hospital.

\section{Limitations of the study}

One of the limitations of this research consists in the lack of other studies in the literature with this focus, which makes comparisons impossible. Another limitation is the constitution of the sample by nursing professionals of only one hospital. 
Contributions to the field of nursing, health or public policy

The assessment of the safety climate in the perception of these professionals can subsidize nursing managers and administrators in identifying the existing constraints and weaknesses, to establish measures to promote patient safety. Once the nurses take up a major role in the management of care and health services quality, the finding of this study has great significance for the management of the institution.

\section{CONCLUSION}

When assessing, in this study, the perceptions of nursing professionals on the safety climate, results pointed to a positive perception about safety attitude only to the domain job satisfaction. However, in assessing the perception among the professional categories, the nurses reported higher average values of the scores for all SAQ domains compared with technicians and nursing assistants, reporting a positive perception of the atmosphere of teamwork, safety climate, job satisfaction and safe behavior. The perception on the safety attitude was influenced by time of experience in the unit and in the institution and the intention to leave the profession.

We highlight the importance of this study, both from the care point of view and from the managerial, considering that the study may assist in the implementation of strategies for the consolidation of a safety culture in health care institutions.

\section{FUNDING}

Financial support from the Foundation for Research Support of the State of São Paulo (Fundação de Amparo à Pesquisa do Estado de São Paulo -FAPESP), Brazil, case nº 2013 / 05096-6.

\section{REFERENCES}

1. Sherwood G, Barnsteiner J. Quality and safety in nursing: a competency approach to improving outcomes. lowa: Wiley-Blackwell; 2012.

2. Hwang JI, Hwang EJ. Individual and work environment characteristics associated with error occurrences in Korean public hospitals. J Clin Nurs [Internet]. 2011[cited 2015 Oct 21];20(21-22):3256-66. Available from: http://onlinelibrary.wiley.com/ doi/10.1111/j.1365-2702.2011.03773.x/epdf

3. Levinson DR. Adverse event in skilled nursing facilities: national incidents among medicare beneficiaries. USA: Department of Health and Human Resources. 2014.

4. International Council of Nurses (ICN). Nurses: a force for change care effective, cost effective. Switzerland: ICN. 2015.

5. Kohn LT, Donaldson MS. To err is human: building a safer health system. Institute of Medicine. National Academy Press. 2000.

6. Gandhi TK, Berwick DM, Shojania KG. Patient Safety at the crossroads. JAMA[Internet]. 2016[cited 2015 Oct 21];315(17):182930. Available from: https://jamanetwork.com/journals/jama/fullarticle/10.1001/jama.2016.1759

7. Ausserhofer D, Schubert M, Desmedt M, Blegen MA, De Geest S, Schwendimann R. The association of patient safety climate and nurse-related organizational factors with selected patient outcomes: a cross-sectional survey. Int J Nurs Stud[Internet]. 2013[cited 2015 Oct 21];50(2):240-52. Available from: http://www.journalofnursingstudies.com/article/S0020-7489(12)00145-9/fulltext

8. Norris B, Currie L, Lecko C. The importance of applying human factors to nursing practice. Nurs Stand[Internet]. 2012 [cited 2015 Oct 21];26(32):36-40. Available from: https://www.ncbi.nlm.nih.gov/pubmed/22594204

9. The Joint Commission. Improving patient and worker safety: opportunities for synergy, collaboration and innovation [Internet]. Oakbrook Terrace, IL: The Joint Commission, 2012 [cited 2015 Oct 21]. Available from: http://www.jointcommission.org/ assets/1/18/TJC-ImprovingPatientAndWorkerSafety-Monograph.pdf

10. Singer SJ, Vogus TJ. Reducing hospital errors: interventions that build safety culture. Annu Rev Public Health [Internet]. 2013[cited 2015 Oct 21];34:373-96. Available from: https://www.ncbi.nlm.nih.gov/pubmed/23330698

11. Schneider B, Ehrhart MG, Macey WH. Organizational climate and culture. Annu Rev Psychol[Internet]. 2013 [cited 2015 Oct 21];64:361-388. Available from: https://www.ncbi.nlm.nih.gov/pubmed/22856467

12. Taylor JA, Pandian R. A dissonant scale: stress recognition in the SAQ. BMC Res Notes[Internet]. 2013[cited 2015 Oct 21$] ; 6: 302$. Available from: https://www.ncbi.nlm.nih.gov/pmc/articles/PMC3733616/pdf/1756-0500-6-302.pdf

13. Carvalho RE, Cassiani SHB. Cross-cultural adaptation of the Safety Attitudes Questionnaire: short form 2006 for Brazil. Rev Latino-Am Enfermagem[Internet]. 2012[cited 2015 Oct 21];20(3):575-82. Available from: http://www.scielo.br/pdf/rlae/v20n3/ a20v20n3.pdf

14. Sampieri RH, Collado CF, Lucio MDPB. Metodologia de pesquisa. Porto Alegre: Penso; 2013.

15. Rigobello MC, Carvalho RE, Cassiani SH, Galon T, Capucho HC, Deus NN. The climate of patient safety: perception of nursing professionals. Acta Paul Enferm[Internet]. 2012[cited 2015 Oct 21];25(5):728-35. Available from: http://www.scielo.br/pdf/ape/ v25n5/en_13.pdf

16. Profit J, Etchegaray J, Petersen LA, Sexton JB, Hysong SJ, Mei M, et al. The safety attitude questionnaire as a tool for benchmarking safety culture in the NICU. Arch Dis Child Fetal Neonatal[Internet]. 2012[cited 2015 Oct 21];97:F127-32. Available from: https:// www.ncbi.nlm.nih.gov/pmc/articles/PMC4030665/pdf/nihms578872.pdf 
17. Raftopoulos V, Pavlakis A. Safety climate in 5 intensive care units: a nationwide hospital survey using the Greek-Cypriot version of the safety attitude questionnaire. J Crit Care[Internet]. 2013[cited 2015 Oct 21];28(1):51-61. Available from: https://linkinghub. elsevier.com/retrieve/pii/S0883-9441(12)00152-9

18. Marinho MM, Raunz V, Barbosa SF. Assessment of safety culture by surgical unit nursing teams. Texto Contexto Enferm[Internet]. 2014[cited 2015 Oct 21];23(3):581-90. Available from: http://www.scielo.br/pdf/tce/v23n3/0104-0707-tce-23-03-00581.pdf

19. Scwendimann R, Zimmermann N, Kung K, Ausserhofer D, Sexton B. Variation in safety culture dimensions within and between US and Swiss hospitals units: an exploratory study. BMJ Qual Saf[Internet]. 2013[cited 2015 Oct 21];22(1):32-41. Available from: http://qhc.bmj.com/cgi/pmidlookup?view = long\&pmid = 22773888

20. Hamdan M. Measuring safety culture in Palestinian neonatal intensive care units using the safety attitudes questionnaire. J Crit Care[Internet]. 2013[cited 2015 Oct 21];28(5):886.e7-e14. Available from: https://linkinghub.elsevier.com/retrieve/pii/ S0883-9441(13)00177-9

21. Alayed AS, Lööf H, Johansson UB. Saudi Arabian ICU safety culture and nurse's attitudes. Int J Health Care Qual Assur[Internet]. 2014[cited 2015 Oct 21];27(3):581-93. Available from: https://www.ncbi.nlm.nih.gov/pubmed/25252564

22. Feng X, Bobay K, Krejci JW, McCormick BL. Factors associated with nurses' perceptions of patient safety culture in China: a cross-sectional survey study. J Evid Based Med[Internet]. 2012[cited 2015 Oct 21];5(2):50-6. Available from: http://dx.doi. org/10.1111/j.1756-5391.2012.01177.x

23. Chen MF, Ho CH, Lin CF, Chung MH, Chao WC, Chou HL, Li CK. Organisation-based self-esteem mediates the effects of social support and job satisfaction on intention to stay in nurses. J Nurs Manag[Internet]. 2016[cited 2015 Oct 21];24(1):88-96. Available from: http://dx.doi.org/10.1111/jonm.12276

24. Van der Heijden BI, Kummerling A, Van Dam K, Van der Schoot E, Estryn-Béhar M, Hasselhorn HM. The impact of social support upon intention to leave among female nurses in Europe: secondary analysis of data from the NEXT survey. Int J Nurs Stud[Internet]. 2010[cited 2015 Oct 21];47(4):434-45. Available from: https:/www.ncbi.nlm.nih.gov/pubmed/17890991 